\section{BUKU AJAR \\ MODEL PENDIDIKAN AGAMA HINDU \\ BERBASIS GLOKALISASI DAN}

PARADIGMA REKONSTRUKSI SOSIAL VYGOTSKY

Model pembelajaran merupakan tingkatan tertinggi dalam kerangka pembelajaran karena mencakup keseluruhan tingkatan. Lingkupnya yaitu keseluruhan kerangka pembelajaran karena memberikan pemahaman dasar atau filosofis dalam pembelajaran. Dalam model pembelajaran, terdapat strategi yang menjelaskan operasional, alat, atau teknik yang digunakan siswa dalam prosesnya. Selanjutnya, di dalam strategi pembelajaran ada metode pembelajaran yang menjelaskan langkah-langkah untuk mencapai tujuan pembelajaran. Tingkatan ini memiliki fungsi untuk menjelaskan hubungan dari kerangka pembelajaran tersebut. Istilah model pembelajaran ini sering diartikan sebagai pendekatan pembelajaran. Dalam pendekatan pembelajaran, di dalamnya terdapat rencanarencana dan alur yang digunakan sebagai petunjuk dalam merencanakan pembelajaran di kelas.

Arus globalisasi yang semakin berkembang di era modern ini, dimana semua aspek terkena dampaknya, mulai dari aspek ekonomi, sosial budaya dan pendidikan. Arus globalisasi dengan ciri utama yaitu perkembangan ilmu pengetahuan dan teknologi yang awalnya berasal dari Barat, menghegemoni Indonesia menjadi pihak yang dipengaruhi daripada mempengaruhi. Aspek ekonomi misalnya model ekonomi kapitalisme dalam kepemilikan modal, munculnya model baru transaksi via online, menggerus model jual beli kla-sik yang harus datang disetiap warung dan asas gotong royong dalam koperasi. Glokalisasi berarti menjadikan nilai-nilai global sebagai bagian dari sistim nilai lokal melalui adaptasi yang terstruktur terhadap nilai-nilai global, sehingga pemertahanan nilai lokal akan tetap bisa dilakukan, dan sebaliknya nilai-nilai global kita transformasi dan integrasikan kedalam nilai lokal itu sendiri, yang pada akhirnya akan memperkaya dan memperkuat khasanah lokal genius kebangsaan kita sendiri.

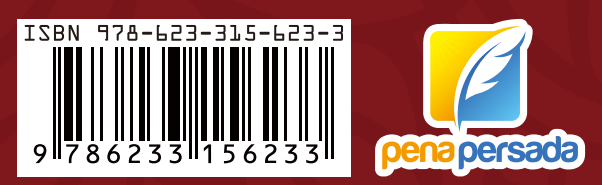

Dr. Ni Nyoman Lisna Handayani, M.Pd I Putu Suardipa, S. Pd., M. Pd.

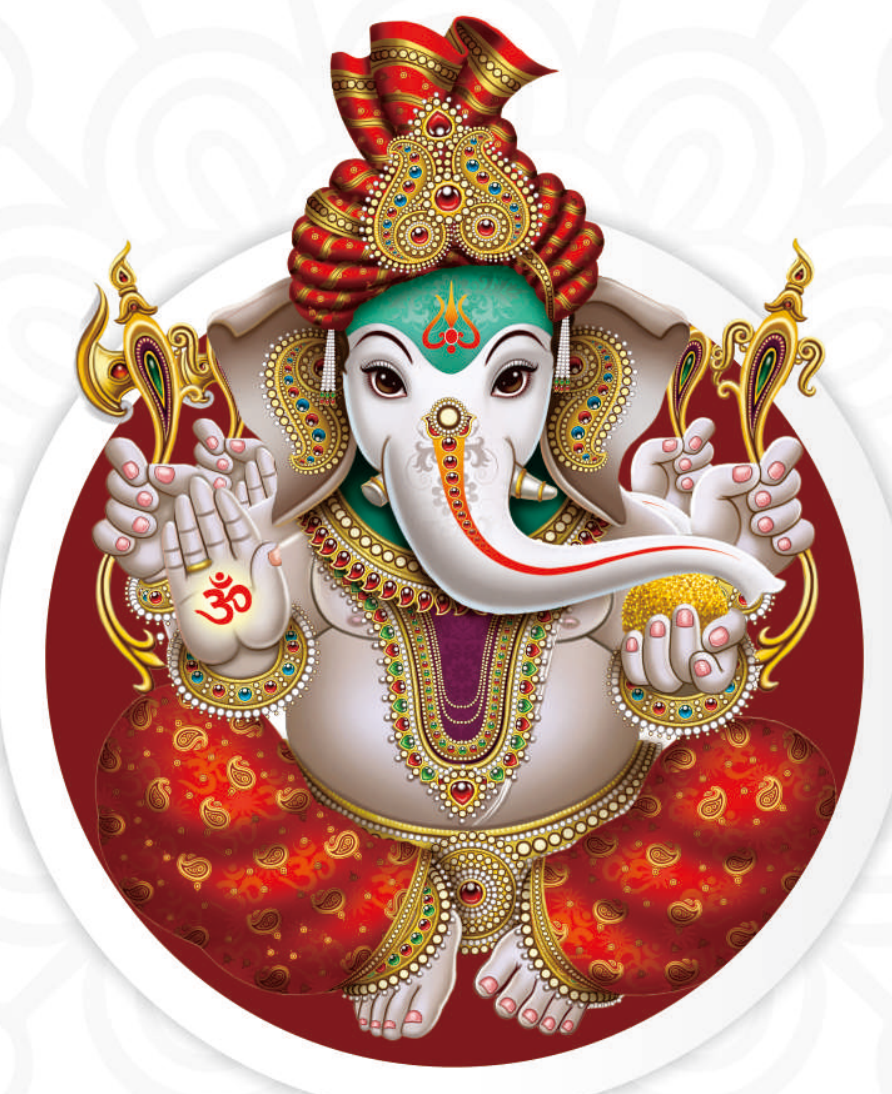

BUKU AJAR

MODEL PENDIDIKAN AGAMA HINDU

BERBASIS GLOKALISASI DAN

PARADIGMA REKONSTRUKSI SOSIAL VYGOTSKY 


\section{BUKU AJAR \\ MODEL PENDIDIKAN AGAMA HINDU BERBASIS GLOKALISASI DAN PARADIGMA REKONSTRUKSI SOSIAL VYGOTSKY}

Dr. Ni Nyoman Lisna Handayani, M.Pd

I Putu Suardipa, S. Pd., M. Pd.

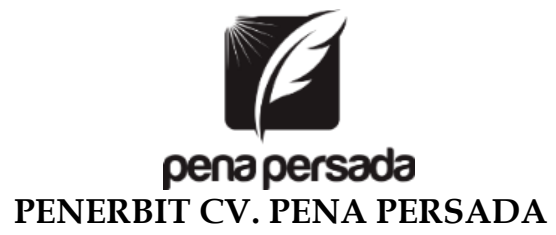




\title{
BUKU AJAR \\ MODEL PENDIDIKAN AGAMA HINDU \\ BERBASIS GLOKALISASI DAN PARADIGMA \\ REKONSTRUKSI SOSIAL VYGOTSKY
}

\author{
Penulis: \\ Dr. Ni Nyoman Lisna Handayani, M.Pd \\ I Putu Suardipa, S. Pd., M. Pd.
}

ISBN : 978-623-315-623-3

Desain Cover:

Retnani Nur Briliant

Layout:

Nisa Falahia

Penerbit CV. Pena Persada

Redaksi:

Jl. Gerilya No. 292 Purwokerto Selatan, Kab. Banyumas

Jawa Tengah

Email : penerbit.penapersada@gmail.com

Website : penapersada.com Phone : (0281) 7771388

Anggota IKAPI

All right reserved

Cetakan pertama : 2021

Hak Cipta dilindungi oleh undang-undang. Dilarang memperbanyak karya tulis ini dalam bentuk apapun tanpa izin penerbit 


\section{KATA PENGANTAR}

Teriring ucapan puji syukur kehadirat Tuhan Yang Maha Esa, atas segala nikmat dan karuniaNya yang diberikan kepada kita semua, sehingga sampai hari ini kita masih diberikan kesehatan dan kesempatan untuk menjalankan sebagian kecil dari perintah Tuhan dalam menyebarkan kebaikan di dunia untuk bekal di akhirat kelak. Pertama, saya ucapkan terima kasih kepada LPPPM STAHN Mpu Kuturan Singaraja yang telah menginisiasi terbitnya buku Ajar ini. Sungguh penerbitan buku ajar ini adalah bagian yang harus selalu dijadikan tradisi baik dilingkungan perguruan tinggi, khususnya di STAHN Mpu Kuturan Singaraja. Buku Ajar yang diberi judul: "MODEL PENDIDIKAN AGAMA HINDU BERBASIS GLOKALISASI DAN PARADIGMA REKONSTRUKSI SOSIAL VYGOTSKY" adalah refleksi kita bersama sebagai insan akademis yang memiliki tanggungjawab moral untuk meningkatkan kapasitas intelektual dalam membangun tradisi ilmiah dilingkungan perguruan tinggi.

Penerbitan Buku ajar ini harus dijadikan sebagai momentum dalam mempersuasikan para Insan akademis lainnya untuk terus berkontribusi pemikiran, gagasan dan visi terkait proyeksi pengembangan kemampuan kognitif. Dalam buku ini para penulis dengan latar belakang keilmuan pendidikan dasar mencoba memotret peluang dan apa yang harus dilakukan oleh Perguruan Tinggi secara umum dan apa yang harus dilakukan oleh Dosen sebagai tenaga akademisi. Pendidikan merupakan sebuah keniscayaan bagi sebuah Negara dalam rangka mencerdaskan kehidupan bangsa, tidak ada Negara yang maju tanpa mengabaikan pendidikan. sebesar negara- negara maju seperti Jepang sekalipun, ia tidak pernah meninggalkan dunia pendidikan sebagai basis pembangunan sumberdaya manusianya. Oleh karena itu, berbagai tantangan dalam dunia pendidikan yang ada saat ini, hendaknya tidak dijadikan sebagai alas an untuk berhenti berbuat dan berkontribusi secara nyata bagi masyarakat. Saat anda berhenti, maka disaat itulah kemunduran sebuah bangsa akan terjadi, tanpa anda sadari. 
Sungguh saya menyambut baik gagasan dan ide cerdas para Dosen dan penulis dalam buku ini yang telah menuangkan gagasan dan pemikirannya untuk menkonstruksi sebuah peluang dan tantangan apa yang harus dihadapi oleh sebuah Negara dalam bidang pendidikan, khususnya pendidikan tinggi. Saya percaya, bahwa berbagai pemikiran yang ada dalam buku ini merupakan kontribusi yang tidak bisa dinilai dengan nilai materi, bahkan dengan apapun ia tidak bias dinilai. Oleh karena itu, saya mengucapkan selamat dan sukses kepada para penulis yang sudah berkontribusi dalam penulisan buku ajar ini. Semoga Tuhan Yang Maha Esa memberi balasan yang baik kepada kita semua, dan apa yang kita lakukan dapat bermanfaat bagi kemaslahatan orang banyak.

Singaraja 17 Agustus 2021,

Penulis 


\section{DAFTAR ISI}

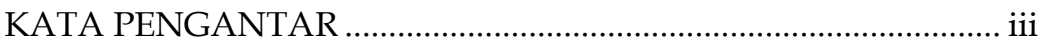

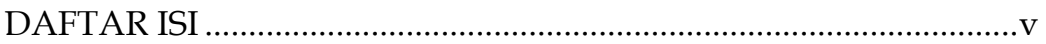

BAB I PENDIDIKAN AGAMA HINDU DI SD …………...................

Capaian pembelajaran:............................................................. 1

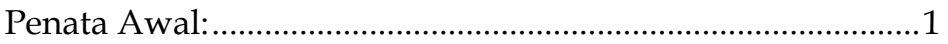

1.1 Hakekat Pendidikan Agama Hindu ......................................

1.2 Tujuan Pendidikan Agama Hindu di SD ...............................

1.3 Komponen Terkait dalam Pembentukkan Karakter

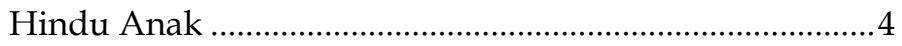

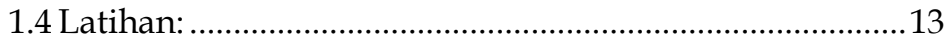

BAB II DASAR-DASAR PEMBELAJARAN AGAMA HINDU

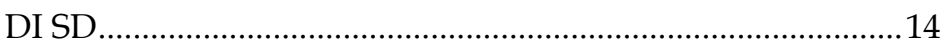

2.1 Hakikat Proses Pembelajaran Agama Hindu di SD ........15

2.2 Pembelajaran Sebagai Reflektif .......................................17

2.3 Perkembangan Sebagai Tujuan Pembelajaran .................19

2.4 Prinsip-prinsip Perkembangan .........................................22

2.5 Aspek-Aspek Perkembangan Anak....................................29

2.6 Pendekatan Perkembangan dalam Pembelajaran

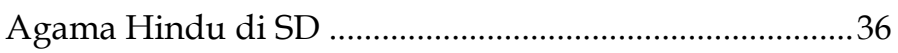

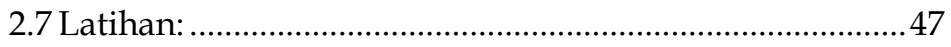

BAB III KONSEP BELAJAR, MENGAJAR, DAN

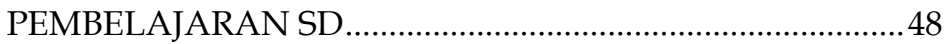

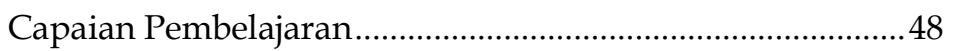

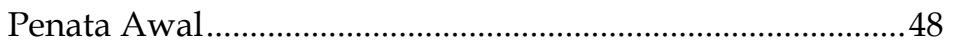

3.1 Definisi Belajar, Mengajar, dan Pembelajaran................... 49

3.2 Jenis-jenis Belajar ................................................................53

3.3 Prinsip-prinsip Belajar Mengajar ……………………….....5

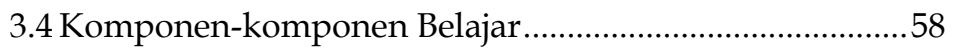

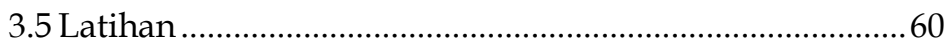

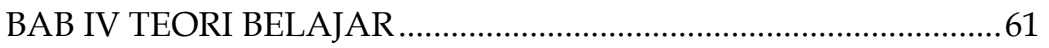

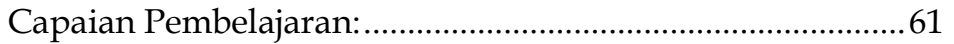

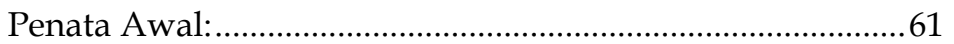

4.1 Teori Perkembangan Kognitif Piaget .................................... 61

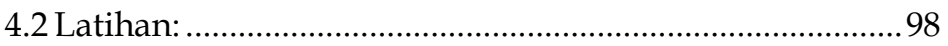


UNIT V KONSEP PENDEKATAN, STRATEGI, MODEL,

METODE DAN TEKNIK PEMBELAJARAN

PENDIDIKAN AGAMA HINDU …………………............. 99

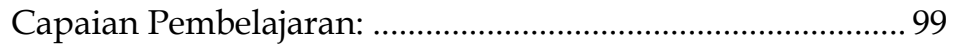

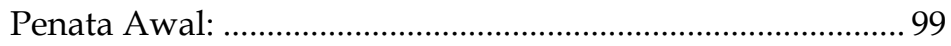

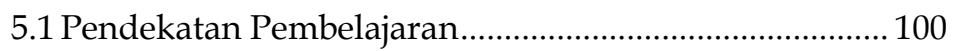

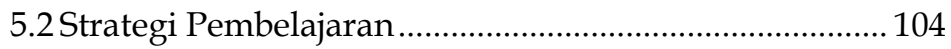

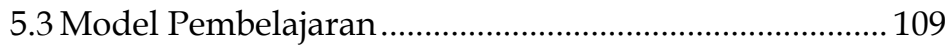

5.4 Metode Pembelajaran ....................................................... 113

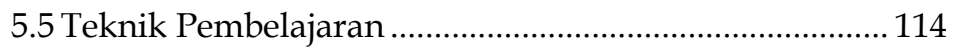

5.6 Hubungan Pendekatan, Strategi, Model, Metode dan

Teknik Pembelajaran ...................................................... 114

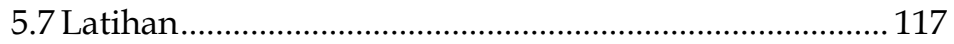

UNIT VI KONSEP PEMBELAJARAN DALAM KONTEKS

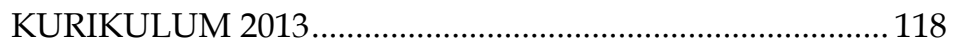

Capaian Pembelajaran: ....................................................... 118

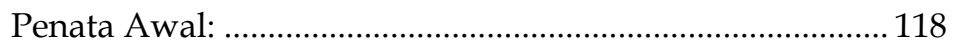

6.1 Konsep Inovasi dalam Pembelajaran ............................... 120

6.2 Pembelajaran yang Berpusat pada Peserta Didik.......... 123

6.3 Perspektif Konstruktivis dalam Pembelajaran .............. 129

6.4 Pembelajaran Kontekstual (Contextual Teaching and Learning) ........................................................................ 131

6.5 Pendekatan Ilmiah (Scientific Approach) dalam

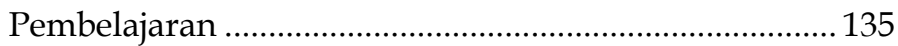

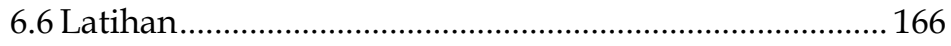

UNIT VII STANDAR PENDIDIKAN AGAMA HINDU PADA

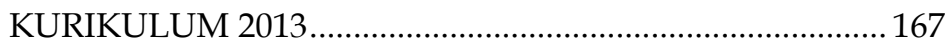

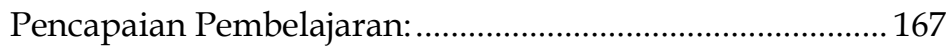

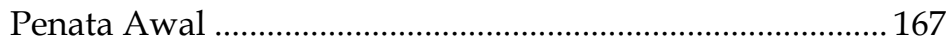

7.1 Standar Kompetensi Lulusan (SKL) .................................. 169

7.2Standar Isi .................................................................... 172

7.3Standar Proses .................................................................. 174

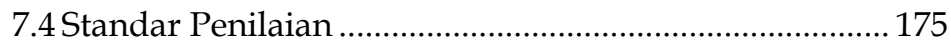

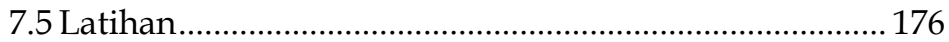


UNIT VIII GLOKALISASI KURIKULUM PENDIDIKAN

AGAMA DI ERA 4.0............................................................177

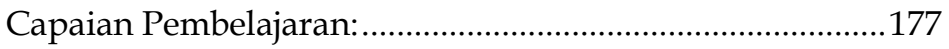

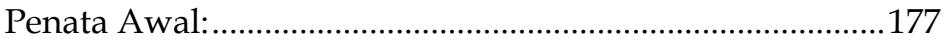

8.1 Nilai-nilai Karakter Global Berdasarkan Spektrum

Teori Rekonstruksi Sosial Vygotsky ................................178

8.2 Pola atau Model Pengorganisasian Domain Aksiologi

Pendidikan Agama Hindu di SD ......................................184

8.3 Konteks Pengorganisasian Materi Kurikulum

Pendidikan Agama Hindu ................................................188

8.4 Tahap Penyusunan Glokalisasi Kurikulum

Pendidikan Agama Hindu di Era Revolusi Industri .....200

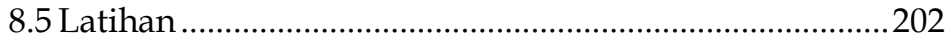

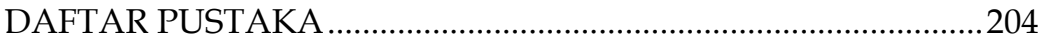

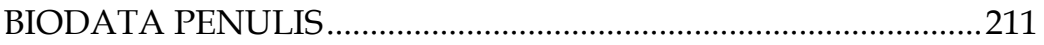




\section{BUKU AJAR \\ MODEL PENDIDIKAN AGAMA HINDU \\ BERBASIS GLOKALISASI DAN PARADIGMA REKONSTRUKSI SOSIAL VYGOTSKY}




\section{BAB I \\ PENDIDIKAN AGAMA HINDU DI SD}

\section{Capaian pembelajaran:}

Mahasiswa mampu memahami hakekat, tujuan pendidikan agama hindu di SD dan Komponen Terkait dalam Pembentukkan Karakter Hindu Anak.

\section{Penata Awal:}

Seiring perkembangan ilmu pengetahuan dan teknologi serta era globalisasi dunia, pendidikan semakin dihadapkan pada berbagai tantangan dan permasalahan yang lebih kompleks. Pengaruh yang ditimbulkan dalam kehidupan masyarakat khususnya kehidupan peserta didik mengarah pada hal-hal yang bersifat negatif. Menurunnya rasa kebersamaan, munculnya kehidupan yang individualis sehingga melemahkan rasa toleransi, meningkatnya sifat konsumtiisme, munculnya radikalisme, tawuran antarpelajar, kenakalan remaja, pengaruh narkoba, menurunnya etika dan moral, merebaknya video porno melalui telepon seluler, serta anarkis, merupakan hal-hal yang mengakibatkan rusaknya mental peserta didik. Dari segi pedagogik, sistem pembelajaran agama Hindu dianggap kurang menarik bagi peserta didik, antara lain metodologi pembelajaran yang kurang menarik, tenaga pendidik yang kurang profesional, media yang belum mendukung proses pembelajaran, pembelajaran kontekstual dalam Pendidikan Agama Hindu belum memadai.

\subsection{Hakekat Pendidikan Agama Hindu}

Seiring perkembangan ilmu pengetahuan dan teknologi serta era globalisasi dunia, pendidikan semakin dihadapkan pada berbagai tantangan dan permasalahan yang lebih kompleks. Pengaruh yang ditimbulkan dalam kehidupan masyarakat khususnya kehidupan peserta didik mengarah 
pada hal-hal yang bersifat negatif. Menurunnya rasa kebersamaan, munculnya kehidupan yang individualis sehingga melemahkan rasa toleransi, meningkatnya sifat konsumtiisme, munculnya radikalisme, tawuran antarpelajar, kenakalan remaja, pengaruh narkoba, menurunnya etika dan moral, merebaknya video porno melalui telepon seluler, serta anarkis, merupakan hal-hal yang mengakibatkan rusaknya mental peserta didik. Dari segi pedagogik, sistem pembelajaran agama Hindu dianggap kurang menarik bagi peserta didik, antara lain metodologi pembelajaran yang kurang menarik, tenaga pendidik yang kurang profesional, media yang belum mendukung proses pembelajaran, pembelajaran kontekstual dalam Pendidikan Agama Hindu belum memadai.

Hakikat Pendidikan Agama Hindu pendidikan agama hindu yang bersumber pada Kitab Suci Veda selalu mengarah pada konsep Tri Kaya Parisudha berpikir yang baik, berkata yang baik, dan berbuat yang baik sehingga terwujudnya manusia berbudi pekerti yang luhur kepada Sang Hyang Widhi. Pendidikan agama Hindu selalu mengajarkan tentang hakikat Satyam kejujuran, Siwam kesucian, Sundaram keindahan sehingga mampu menumbuhkan perilaku yang menjunjung tinggi nilai-nilai kebenaran di lingkungannya. Pendidikan Agama Hindu yang paling penting adalah menjunjung tinggi dharma. Salah satu contoh dharma adalah nilai Sradha, yakni keyakinan akan Brahman, keyakinan akan Atman, keyakinan akan Karmaphala, keyakinan akan Punarbhawa dan keyakinan akan adanya Moksha. Pendidikan Agama Hindu juga menekankan pada dua aspek, yaitu aspek Paroksah dan Aparoksah Widya dan Apara Widya sehingga dapat melahirkan insan Hindu yang Sadhu Gunawan. 


\subsection{Tujuan Pendidikan Agama Hindu di SD}

Setiap agama pasti memiliki tujuan untuk senantiasa menuntun umatnya ke jalan yang benar hingga mencapai kebahagiaan yang hakiki. Keyakinan akan Tuhan yang Maha Pengasih memeberi anak kekuatan dan pedoman. Agama menjadi pedoman bagi umat manusia dalam menjalankan kehidupannya, dapat dibayangkan jika manusia tidak memiliki pedoman dalam hidupnya, manusia akan kehilangan arah karena, tidak adanya aturan yang mengarahkan manusia tersebut dalam bersikap. Seperti yang dikatakan sebelumnya bahwa, agama juga memberi kekuatan bagi mereka yang meyakini Tuhan karena, sumber kekuatan yang sebenarnya berasal dari hati mereka yang senantiasa percaya bahwa Tuhan lah yang maha atas segala sesuatunya sehingga, apapun yang terjadi itu karena Tuhan.

Pembentukan karakter Hindu yang dilakukan sekolah dapat sangat membantu anak untuk lebih mematangkan pemahaman konsep agamanya selain itu, memberikan pengertian bahwa agama sangatlah penting sebagai pedoman dalam menjalani kehidupan. Jika pengembangan agama ini sudah dibiasakan sejak kecil maka, anak tidak akan asing lagi dengan segala aturan atau norma yang terkandung dalam ajaran agama. Adapun definisi serupa yang menjelaskan tentang tujuan agama Hindu. Tujuan agama Hindu yang dirumuskan sejak Weda mulai diwahyukan adalah "Moksartham Jagadhitaya ca iti Dharma", yang artinya bahwa agama (dharma) bertujuan untuk mencapai kebahagiaan rohani dan kesejahteraan hidup jasmani atau kebahagiaan secara lahir dan bathin. Setiap agama pasti memiliki tujuan yang hendak dicapai tidak terkecuali pada agama Hindu yang memiliki tujuan untuk para umat sedharma. Tujuan ini dapat dicapai dengan mengamalkan ajaran-ajaran yang ada dalam kitab suci agama Hindu yaitu Veda (Weda) dengan maksud untuk memberikan kebahagiaan secara lahir dan bathin. 
Jika dilihat secara keseluruhan agama memiliki tujuan yang sama dengan agama lain terlepas dari apa agama tersebut. Secara umum agama bertjuan untuk menjadikan umatnya memiliki pedoman dalam hidup, memiliki ramburambu kehidupan yang berfungsi mengatur segala tingkah pola umatnya dalam berinteraksi dengan seluruh ciptaanNya. Mendekatkan umat manusia kepada sang pencipta, saling menghormati dan mengasihi antar sesama, dan lain sebagainya. Selain itu, dapat disebutkan juga bahwa agama Hindu bukan hanya memberikan ketenangan dan kebahagiaan secara duniawi namun, juga memberikan ketenangan bagi rohani dan memberikan kebahagiaan secara lahir dan bathin.

\subsection{Komponen Terkait dalam Pembentukkan Karakter Hindu Anak}

Belajar adalah proses perubahan tingkah laku anak. Dalam pembentukkan karakter terdapat komponenkomponen yang menyertai berjalannya proses tersebut seperti; kurikulum, materi, metode, media, proses pembelajaran, dan, evaluasi.

a. Kurikulum

Kurikulum menjadi kmponen yang penting dalam membentuk karakter anak karena, kurikulum berisi tentang muatan materi yang akan diberikan kepada anak didik. Menurut UU. No. 20 Tahun 2003 tentang Sietem Pendidikan Nasional, "Kurikulum adalah seperangkat rencana dan pengaturan mengenai tujuan, isi, dan bahan pelajaran serta cara yang digunakan sebagai pedoman penyelenggaraan kegiatan pembelajaran untuk mencapai tujuan pendidikan tertentu". Kurikulum tidak hanya berisi tentang isi atau konten pelajaran tetapi juga mencakup semua kegiatan yang akan dilakukan oleh anak, evaluasi yang akan dilakukan, bagaimana metode dan media yang akan digunakan sampai dengan tujuan yang diharapkan dari semua program yang telah dirancang oleh guru. 
Kurikulum atau materi ajar atau bahan ajar berisi tentang pengetahuan yang akan diberikan kepada anak. Sehubungan dengan ini, Hamalik juga mendeskripsikan tentang kurikulum yaitu, kurikulum ialah sejumlah mata ajaran yang harus ditempuh dan dipelajari oleh siswa untuk memperoleh sejumlah pengetahuan. Sesuai dengan namanya, kurikulum tidak hanya berisi satu mata pelajaran melainkan, sejumlah mata pelajaran yang dimasukkan ke dalam program sekolah sehingga, anak mendapatkan pengetahuan yang lebih banyak dan lebih kompleks.

Kurikulum yang diracang oleh guru memuat suatu kegiatan di dalam maupun di luar kelas yang akan dilakukan oleh anak. Hal ini sama dengan apa yang dikemukakan oleh Patmodewo tentang kurikulum adalah seluruh usaha/kegiatan sekolah untuk merangsang anak supaya belajar, baik di dalam maupun di luar kelas. Kurikulum yang dibuat berisi serangkaian program yang akan dilaksanakan bersama dengan anak. Program yang dibuat tidak hanya terpaku pada kegiatan di dalam kelas tetapi juga kegiatan di luar kelas, dengan maksud agar murid mendapat suasana baru dalam belajar dan pengalaman belajar yang lebih bermakna. Program yang dirancang dalam kurikulum juga memudahkan guru dalam mengajar karena, guru sudah memiliki acuan untuk melaksanakan proses pembelajaran.

Kurikulum dirancang sedemikian rupa agar anak dapat memperoleh pengalaman belajar yang bermakna. Kurikulum secara modern adalah semua kegiatan dan pengalaman potensial (isi/materi) yang telah disusun secara ilmiah, baik yang terjadi di dalam kelas, di halaman sekolah maupun di luar sekolah atas tanggung jawab sekolah untuk mencapai tujuan pendidikan. Kurikulum yang dirancang dalam satuan pendidikan memuat isi tentang konten yang akan diberikan juga termasuk kedalamnya kegiatan-kegiatan yang akan dilakukan oleh 
anak. Kegiatan pembelajaran tidak harus terjadi di dalam kelas melainkan, juga dapat terjadi atau dilakukan di luar kelas bahkan di luar sekolah karena, pada dasarnya pembelajaran dapat terjadi dimana saja dan kapan saja.

b. Materi Pembelajaran

Materi pembelajaran dapat disebut juga sebagai bahan ajar atau konten yang akan diberikan kepada anak. Menurut Arikunto mengatakan bahwa, bahan pelajaran merupakan unsur inti yang ada di dalam kegiatan belajar mengajar. Bahan pelajaran atau yang biasa disebut dengan materi menjadi unsur utama dan penting dalam sebuah sebuah pembentukan karakter karena, bahan pelajaran berisi pengetahuan yang akan diberikan kepada anak. Bahan pelajaran yang diberikan juga harus disesuaikan dengan kemampuan anak didik karena, perkembangan kognitif setiap anak tidaklah sama anatara anak satu dengan lainnya.

Materi menjadi komponen utama dalam kegiatan belajar mengajar tanpa materi, proses pendidikan tidak akan berjalan. Hal ini sejalan dengan pernyataan Hamdani yang menyebutkan bahwa materi pelajaran, merupakan komponen utama dalam proses pembelajaran karena materi pelajaran akan memberi warna dan bentuk kegiatan pelajaran. Materi pelajaran dirancang sedemikian rupa oleh guru sesuai dengan kebutuhan di lembaga tersebut sehingga, materi pelajaran ini akan berbeda di setiap lembaga pendidikan. Seperti yang telah dijelaskan sebelumnya, bahwa materi menjadi komponen utama dalam pembelajaran karena materi itu berisi pengetahuan yang akan diberikan kepada anak didik untuk mencapai tujuan tertentu.

Materi atau bahan ajar memuat semua nilai yang akan diberikan kepada anak. Materi atau bahan belajar berisi tentang pengetahuan, ketrampilan dan/atau nilainilai yang akan dikomunikasikan oleh pendidik kepada peserta didik. Materi merupakan komponen utama dalam 
pembelajaran karena materi berisi konten atau isi yang akan diberikan kepada siswa. Materi atau bahan belajar ini dapat disesuaikan dengan kebutuhan anak didik berupa pengetahuan yang akan diberikan kepada anak.

c. Metode Pemblajaran

Metode pembelajaran digunakan guru untuk mencapai tujuan tertentu. Metode adalah suatu cara yang digunakan untuk mencapai tujuan yang telah ditetapkan. Metode juga merupakan komponen penting dalam kegiatan belajar mengajar karena seperti yang telah dijelaskan sebelumnya, metode adalah cara yang digunakan untuk mencapai tujuan tertentu ini berarti posisi metode dalam penyampaian materi ajar memliki peranan penting. Penggunaan metode juga harus dilihat secara cermat, guru harus kreatif dalam menggunakan metode di dalam kelas agar anak tidak merasa jenuh atau bosan sehingga, tujuan yang diharapkan dapat tercapai dengan baik.

Metode digunakan untuk mencapai suatu tujuan yang diharapkan. Hal ini sejalan dengan apa yang dikatakan oleh J.R David dalam Majid menyatakan bahwa metode ialah "a way in achieve something" (cara untuk mencapai sesuatu). Hal tersebut mengandung pengertian bahwa untuk mencapai suatu tujuan dibutuhkan metode yang efektif dan tepat sasaran. Penggunaan metode juga harus disesuaikan dengan kondisi di lapangan. Guru harus cermat dalam menentukan metode apa yang tepat digunakan karena, setiap anak memiliki karakteristik yang berbeda sehingga, metode yang digunakan pun harus bervariasi agar tujuan tersebut dapat tercapai dengan baik.

Metode digunakan oleh guru untuk mencapai tujuan pembelajaran yang diharapkan. Adanya metode dapat memudahkan guru dalam menyusun strategi agar pembelajaran yang terjadi tidak membuat anak merasa jenuh dan bosan. Metode pembelajaran adalah cara yang digunakan oleh guru dalam menyampaikan pesan 
pembelajaran kepada peserta didik dalam mencapai tujuan pembelajaran. Dalam mencapai tujuan pembelajaran guru harus memiliki metode dalam menyampaikan materi yang akan diberikan kepada anak. Metode yang digunakan harus disesuaikan dengan kemampuan anak karena, tidak semua anak dapat memahami materi yang diberikan dengan metode yang sama selain itu, penggunaan metode yang bervariasi juga bermanfaat agar anak tidak merasa jenuh.

Dalam kegiatan belajar mengajar, penting bagi guru untuk menggunakan metode pembelajaran. Metode pembelajaran merupakan cara guru melakukan atau menyajikan, menguraikan, memberi contoh, dan memberi latihan isi pelajaran kepada peserta didik untuk mencapai tujuan tertentu. Oleh sebab itu, penting bagi guru untuk menggunakan metode pembelajaran yang bisa diterapkan pada anak sehingga, tujuan dari pembelajaran dapat tercapai dengan optimal. Seperti yang dijelaskan sebelumnya juga bahwa penggunaan metode pembelajaran dapat menjadikan anak merasa senang karena yang terjadi di dalam kelas tidak monoton pada satu kegiatan saja selain itu, dengan berbagai metode yang digunakan dapat menjadikan anak lebih aktif dalam proses kegiatan belajar mengajar yang terjadi.

Dari beberapa paparan yang telah dijelaskan sebelumnya tentang metode pembelajaran maka, dapat disintesiskan bahwa metode ialah suatu cara yang digunakan guru dalam proses kegiatan belajar mengajar baik di dalam maupun di luar kelas/ruangan. Adanya metode pembelajaran dapat memudahkan guru dalam mencapai tujuan yang diharapkan. Penggunaan metode yang bervariasi juga dapat memunculkan minat belajar anak karena proses melajar mengajar menjadi lebih menyenangkan dan tidak membuat anak bosan/jenuh. 
d. Media Pembelajaran

Media pembelajaran tidak lepas dari peranannya yang penting dalam kegiatan belajar mengajar karena, media pembelajaran dapat memudahkan anak dalam menerima informasi/pesan yang disampaikan oleh guru. Media pembelajaran adalah alat atau wahana yang digunakan dalam proses pembelajaran untuk membantu penyampaian pesan pembelajaran. Media digunakan untuk mentransfer pesan yang ingin disampaikan oleh guru kepada anak didik untuk mencapai tujuan tertentu. Dengan digunakannya media pembelajaran dapat memudahkan anak dalam memahami materi yang disampaikan terlebih jika materi yang disampaikan cukup sulit untuk dipahami maka, kehadiran media ini sangat dibutuhkan oleh guru sebagai fokus dari apa yang akan diajarkan kepada anak. Media dapat digunakan oleh guru untuk membantu menyampaikan pesan selama proses kegiatan belajar mengajar berlangsung. Media pengajaran hanya meliputi media yang dapat digunakan secara efektif dalam proses pengajaran yang terencana. Untuk itu, penting bagi guru dalam memilih media yang tepat sehingga, pesan yang disampaikan dapat diterima oleh anak didik dengan baik.

Media pembelajaran merupakan seperangkat alat yang mengandung pesan. Sanjaya menyatakan bahwa, media pembelajaran meliputi perangkat keras yang dapat mengantarkan pesan dan perangkat lunak yang mengandung pesan.33Satu kesatuan ini tidak dapat dipisahkan karena, perangkat keras dan perangkat lunak ini sama-sama mengandung pesan yang akan disampaikan kepada penerima pesan agar informasi yang disampaikan bisa diterima dengan baik.

e. Proses Pembelajaran

Proses pembelajaran atau proses kegiatan belajar mengajar termasuk ke dalam komponen pembentukan karakter anak. Proses pembelajaran atau kegiatan belajar 
mengajar adalah inti kegiatan dalam pendidikan. Oleh sebab itu, guru memiliki peranan penting dalam menyusun atau merancang proses kegiatan belajar mengajar, sehingga jalannya proses pembelajaran menjadi lebih terarah. Dalam proses belajar mengajar terjadi hubungan timbal balik antara guru dengan anak didik. Proses belajar mengajar merupakan suatu proses yang mengandung serangkaian perbuatan guru dan siswa atas dasar hubungan timbal balik yang berlangsung dalam situasi edukatif untuk mencapai tujuan tertentu. Oleh sebab itu dalam proses pendidikan terjadi interaksi antara guru dengan anak didik. Semakin aktif anak didik dalam berinteraksi maka semakin baik proses belajar mengajar yang terjadi.

Proses belajar mengajar bisa terjadi di dalam maupun di luar kelas atau sekolah karena, pada dasarnya pembelajaran dapat terjadi dimana saja dan kapan saja. Menurut Rahman dan Amri proses belajar mengajar merupakan implementasi dari serangkaian perencanaan yang telah dilakukan oleh guru dalam bentuk proses interaksi dengan siswa di dalam maupun di luar kelas untuk mencapai tujuan tertentu. Kegiatan indoor ataupun outdoor dapat dikatakan sebagai proses pembelajaran selama memiliki dan dapat mencapai tujuan pendidikan yang diharapkan. Anak wajib mengikuti proses pembelajaran untuk mendapatkan pengalaman belajar yang bermakna.

Proses belajar merupakan jalan yang harus ditempuh oleh seorang pelajar atau mahasiswa untuk mengerti suatu hal yang sebelumnya tidak diketahui. Oleh sebab itu, penting bagi anak untuk mengikuti jalannya proses pembelajaran agar dapat menambah dan meningkatkan pengetahuan serta wawasan yang dimiliki oleh anak. 
f. Tujuan Pembelajaran

Tujuan termasuk ke dalam komponen strategi pembelajaran. Tujuan pembelajaran adalah harapan yang ingin dicapai dalam satu tahap tertentu tujuan merupakan komponen yang pertama dan utama. Tujuan pembelajaran adalah target yang diharapkan dari suatu pembelajaran. Tujuan pembelajaran dibuat agar program atau pembelajaran yang dirancang serta dilaksanakan bersama antara guru dan anak menjadi maksimal sehingga tujuan yang diharapkan menjadi optimal.

Dalam kegiatan pembelajaran penting untuk memiliki tujuan dalam pelaksanannya. Tujuan secara eksplisit, diupayakan melalui kegiatan pembelajaran instructional effect, biasanya berupa pengetahuan dan ketrampilan atau sikap yang dirumuskan secara eksplisit dalam tujuan pembelajaran.40Tujuan pembelajaran diwujudkan dalam sikap yang nyata seperti yang telah dijelaskan sebelumnya bahwa tujuan pembelajaran ialah menjadikan anak yang awalnya tidak tahu menjadi tahu. Tercapai atau tidaknya tujuan pembelajaran dapat dilihat dalam bagaimana anak bersikap.

Tujuan pembelajaran yang diharapkan dapat dilihat dari perilaku anak yang telah mendapatkan pengajaran. Seperti yang dijelaskan oleh Roestiyah. N.K bahwa, suatu tujuan pengajaran adalah deskripsi tentang penampilan perilaku (performance) murid-murid yang kita harapkan setelah mereka mempelajari bahan pelajaran yang kita ajarkan. Tujuan pembelajaran diharapkan dapat merubah pola pikir dan tingkah laku anak didik menjadi lebih baik dan sesuai dengan norma masyarakat yang berlaku. Tujuan pembelajaran termasuk ke dalam komponen pembelajaran karena, semua yang dirancang ke dalam kurikulum dan dilaksanakan dengan metode tertentu, menggunakan media yang variatif, semua itu mengarah pada tujuan tertentu yang diharapkan. Maka, dalam 